\title{
Patient's perspective of QOL with respect to different domains of Quality of Life in Cancer patients during inpatient Chemotherapy Treatment or outpatient Radiotherapy Treatment in a tertiary care hospital of New Delhi, India
}

\author{
Article by Kavita Gupta \\ Ph.D. Clinical Research, Texila American University, India \\ E-mail: 16kavitagupta@texilaconnect.com
}

\begin{abstract}
Background: In recent times there had been increase in incidence of cancer in India as nearly two people were diagnosed every minute with cancer. This is mainly attributed to urbanization, industrialization, life style changes, population growth and increased life span. There is no current universally accepted definition for quality of life (QOL) as it takes into account many aspects of life which is very difficult to define and measure. Therefore, there is wide range of concepts and opinions about "quality of life" and, over time, these concepts had been turning to the patient's perception about the disease and treatment and its effects, in an objective and subjective way. Evaluation of quality of life was attempted in two ways, objective assessments done by the interviewer and subjective assessments completed by the patients themselves. Nowadays, QOL could be defined by the WHO as an individual's perception of their own position (experience) in life, in the context of the culture and value systems in their life and in relation to their goals, expectations, standards, and concerns. The proposed study was considered valuable since it emphasized on quality of life as one of the possible outcomes that stressed on the factor that patients with cancer often experienced a loss of control and feelings of helplessness, anxiety and depression during chemotherapy or radiotherapy treatment.

Objectives: This study was conducted to assess the Patient's perspective of QOL with respect to different domains of Quality of Life in Cancer patients during inpatient Chemotherapy Treatment or outpatient Radiotherapy Treatment sessions. The primary objective was to analyze subjective impacting factors of QOL in homogenous surviving cancer patients receiving chemotherapy or radiotherapy sessions. Because patients were the best source of information for QOL data as the patients are the ones who are experiencing the effects of the illness and treatment, therefore they might provide a unique perspective on how QOL could be better assessed and defined with respect to treatment regimens.

Methods: It was a cross-sectional, descriptive, hospital based evaluation study. Total duration of the study was 5 months (December 2015- April 2016), conducted in Medical and Radiation Oncology department of DR. B.L. Kapur Memorial Hospital, New Delhi, India. A convenience sample of 60 patients with cancer was selected. They were further divided into Chemotherapy group $(n=30)$ and Radiotherapy group $(n=30)$. Therefore, 30 cancer patients were on chemotherapy and the other 30 cancer patients were on radiotherapy. Data was obtained through direct interview, using validated Psychological intervention tool in the form of Questionnaire: WHOQOL-Bref Questionnaire, Zung Self-Rating Anxiety scale and Zung Self-Rating Depression scale, which was further managed through a statistical program, using appropriate statistical tests.

Results: A total of 60 cancer patients were included in the study in which Chemotherapy group consisted of 30n cancer patients and Radiotherapy group consisted of 30n cancer patients. In the study, 6(20\%) were males and 24(80\%) were females in the chemotherapy group, and, 15(50\%) were males and 15(50\%) were females in the radiotherapy group. Majority of the patients 32(53.34\%) were in the age range of 46-60 years. The study population had Breast cancer 33(55\%), Head cancer 6(10\%), and Neck cancer 21(35\%). Anxiety affected the Physical domain
\end{abstract}


$(p=0.007)$, Environmental domain $(p=0.036)$ in the Chemotherapy group and Social domain

$(p=0.016)$ in the Radiotherapy group. On the other hand, Depression affected the Social domain $(p=0.043)$ in the Chemotherapy group, and Social domain $(p=0.012)$ in the Radiotherapy group. Values of $p<0.05$ were considered to be statistically significant.

Conclusion: The cancer patients who completed this survey/research study were able to conceptualize their quality of life by clearly stating which areas of their life that was important to them and how satisfied they were with that area. It was observed that in the chemotherapy group, overall health was significantly correlated with the psychological domain $(r=-0.395 ; p=0.031)$, social domain ( $r=-0.429 ; p=0.018)$, and environmental domain $(r=-0.598 ; p<0.001)$ of the WHOQOL-Bref questionnaire. On the other hand, the radiotherapy group showed no significant difference.

Keywords: Cancer, Chemotherapy, Radiotherapy, Quality of Life, WHOQOL-Bref Questionnaire, Zung Self-Rating Anxiety scale, Zung Self-Rating Depression scale, Physical domain, Psychological domain, Social domain, Environmental domain, Patient-reported outcomes, Open-ended questions, Overall Health satisfaction.

\section{Abbreviations}

$\begin{array}{lll}\text { QOL } & : \text { Quality of life } \\ \text { QLQ } & : \text { Quality life Questionnaire } \\ \text { WHOQOL-Bref } & : \text { World Health Organization Quality of life assessment-a short brief } \\ & \text { version } \\ \text { ZSAS } & : \text { Zung Self-Rating Anxiety scale } \\ \text { ZSDS } & : \text { Zung Self-Rating Depression scale } \\ \text { CT } & : \text { Chemotherapy Treatment } \\ \text { RT } & : \text { Radiotherapy Treatment; } \\ \text { DOM } & : \text { Third Party Administrator } \\ \text { TPA } & : \text { Fine needle aspiration cytology } \\ \text { FNAC } & : \text { Standard Deviation. } \\ \text { SD } & \end{array}$

\section{Introduction}

Cancer is the second most common disease in India responsible for maximum mortality with about 0.3 million deaths per year ${ }^{[1]}$. In India, life expectancy at birth and risk of cancer had risen from 45 years in 1971 to 62 years in 1991 to 71 years expected by 2021-25 ${ }^{[2]}$. According to the International Agency for Research on cancer (IARC), a group chartered by the World Health Organization; cancers of the breast, head and neck were some of the most frequently occurring forms of cancer in both the male and female population of India ${ }^{[3]}$. India contributed up to $7.8 \%$ of the global cancer burden and $8.33 \%$ of global cancer deaths ${ }^{[4]}$. Cancer prevalence in India was estimated to be around 2.0 to 2.5 million, with over 7-8 lakh new cases detected every year and 4-5 lakh cancer deaths per year ${ }^{[5,6]}$. The incidence of cancer in Delhi was the fourth highest among Asian registries ${ }^{[7]}$. According to 
National Cancer Registry Program (NCRP) 2013 report, cancer was a threatening problem in India with an estimated 2.5 million people living with the disease with 19746 cases (29.8 \% of all cancer in men and $10.6 \%$ of all cancer in women) in Delhi alone ${ }^{[8,9]}$. According to Ferrans (1996) concept, Quality of life could only be defined by the individual in terms of particular period of time between the hopes and expectations of the individual's present experiences and lifestyle, past experience, hopes for the future, dreams and ambitions ${ }^{[10]}$. Patient-centered care theory postulated by the Institute of Medicine (IOM) in the year 2001 had been found to be associated with improved patient satisfaction, better treatment adherence, improved recovery and health outcomes, reduced readmission rates and better seeking of follow-up care ${ }^{[11]}$.

\section{Aims}

The main objectives of the present study was:

i. To determine the association and relationship of two standalone questions in WHOQOL-Bref regarding Overall QOL and Health satisfactionwith different domains of quality of life in cancer patients during chemotherapy treatment or radiotherapy treatment.

ii. To evaluate the patient's perspectives of QOL during Chemotherapy or Radiotherapy treatment regimen through close-ended questions that were asked in between the counseling session to understand the depth of QOL of cancer patients during the course treatment.

iii.To qualitatively analyze the patient's perspectives regarding QOL through subjective openended discussion.

\section{Patients and methods}

During the conduct of the proposed study Ethical Procedures were respected.After obtaining authorized Ethical approval (Ref. No.: IRB/AARCE/5/DEC/2015/1 and dated December $7^{\text {th }}$, 2015) for the research study protocol from IRB and Ethical committee from Dr. B.L. Kapur Memorial Hospital, New Delhi, patients and their caregivers were approached in the inpatient as well as, outpatient clinic, where the purpose of the study was explained and they were invited to participate. Patients who agreed to participate were asked to sign an Informed Consent Form followed by the implementation of the instrument in the form of questionnaires.

The RESEARCH DESIGN of the proposed approved study protocol included the following Sampling Technique:

1. Sample Size: The target population of patients undergoing Chemotherapy and Radiotherapy sessions.

Total participants $=60$ divided in the following pattern:

$\mathrm{N}$ (Chemotherapy treatment) $=30 \mathrm{n}$

$\mathrm{N}$ (Radiotherapy treatment) $=30 \mathrm{n}$

2. Eligibility criteria of the study:

\section{Inclusion criteria}

a. Breast cancer and sub-sites of head and neck tumors (e.g., nasopharyngeal, thyroid cancer, and parotid tumors)

b. Patients aged 18years or older,

c. Clinically diagnosed cases.

d. Cancer diagnosis confirmed by biopsy or FNAC,

e. Undergoing/during the treatment sessions

f. Voluntarily agreed to join the study.

g. Aware of diagnosis and predicted prognosis

\section{Exclusion criteria}

a. Inadequate clinical condition (ambulatory and terminally ill patients) to respond to an interview.

b. Have difficulty in understanding the questionnaire or communicating. 
c. Patients who were serious and didn't give consent were excluded from the study.

d. Had a history of psychiatric disorder

e. Choice of chemotherapy drugs and their dosage, irradiation dosage.

3. The study involved primary research by Individual face-to-face interviews with 60 cancer patients undergoing either chemotherapy or radiotherapy treatment sessions through Structured and Valid WHOQOL-Bref Questionnaire. Secondary data was collected by the researcher with the help of patient records available with the TPA department at Dr. B. L. Kapur Memorial Hospital, New Delhi.

4. Eligible patients were identified through an institutional database or by referring physicians and were approached at their simulation appointment. After giving written informed consent from the patient or their caregivers, participants completed the assessment that included the self-report measures.

5. Patients who agreed to participate were asked to sign an informed consent and then the instruments in the form of questionnaire were applied. Subjective areas were covered using case histories.

6. Special care of the potential risks due to emotional distress was taken care of so that their dignity was not harmed.

7. A total of 5-6 interviews were performed per week, in the time and days most suitable for the clinic in the months of December 2015 to April 2016.

8. Each interview lasted approximately 25-60 minutes and all patients were thanked for their participation, valuable time and information in the end.

\section{Results}

\section{(a) Data collection}

Treatment-related symptoms were assessed using a series of interviews through standard questionnaires of WHOQOL-Bref Questionnaire, ZSAS and ZSDS ${ }^{[12,13,14]}$.The questionnaire was provided in a language that the patient could understand (English / Hindi) followed by interview of the patient who was either undergoing chemotherapy or radiotherapy treatment sessions.

i. WHOQOL-Bref Questionnaire: This is an abbreviated version of the instrument WHOQOL100.It consisted of 2 parts- one aimed at the sociodemographic and health aspects and the other at the Quality of Life ${ }^{[12]}$. The latter consisted of 26 questions, being two about quality of life in general and other 24 representing each of the facets that made up the original instrument ${ }^{[12]}$. The questions were organized in 4 domains:

a. Physical domain (DOM1): It included7 questions pertaining to sleep, energy, mobility, the extent to which pain prevents performance of necessary tasks, the need for medical treatment to function in daily life, level of satisfaction with their capacity for work ${ }^{[12]}$.

b. Psychological domain(DOM2): It included6 questions pertaining to the ability to concentrate, self-esteem, body image, spirituality i.e. the extent to which they feel their life is meaningful, the frequency of positive or negative feelings i.e. blue mood, despair, anxiety, depression ${ }^{[12]}$.

c. Social domain (DOM3): It included 3 questions pertaining to satisfaction with personal relationships, social support systems and sexual satisfaction ${ }^{[12]}$.

d. Environmental domain (DOM4): It included 8 questions related to safety and security, home and physical environment satisfaction, finance i.e. does the respondent have enough money to meet their needs, health/social care availability, information and leisure activity accessibility and transportation satisfaction ${ }^{[12]}$.

In addition to the 4 domains, the WHOQOL-Bref included two stand-alone questions, one pertaining to the respondents' rated QOL, and other related to their Satisfaction with Health that were analyzed separately ${ }^{[12]}$. The score of each question ranged from 1 to 5 and higher scores indicated a better evaluation.Raw scores of the respective domains were then transformed from 0-100 with the lowest score of zero and the highest score of 100according to accepted guidelines ${ }^{[12]}$. 
ii. ZSAS: Zung self-rating anxiety scale quality life questionnaire is a likert scale format (scoring on 1 to 4 scale) that was built by a psychiatrist, William W. K. Zung to measure the rate of anxiety with 20 items self-reported examinations with 15 increased anxiety level questions and 5 (Q. no. 5, 9, 13, 17, 19) decreased anxiety questions that were answered by the patients ${ }^{[13]}$. Scores for each question ranged from 1 to 4 and higher scores indicated severe anxiety level. The raw scores were counted up and multiplied by 1.25 to reach a standardized score, according to the instructions that accompanied the scale ${ }^{[13]}$.

iii.ZSDS:Zung self-rating depression scale quality life questionnaireis a 20 items short selfadministered survey that was designed by William W. K. Zung to assess the level of four common characteristics of depression for patients: the pervasive effect, the physiological equivalents, other disturbances, and psychomotor activities. There were ten positively worded and ten negatively worded questions. Each question was scored on a scale of 1-4 (a little of the time, some of the time, good part of the time, most of the time) ${ }^{[14]}$. The higher scores indicated severe depression level. The raw scores were counted up and multiplied by 1.25 to reach a standardized score, according to the instructions that accompanied the scale ${ }^{[14]}$.

\section{(b) Statistical analyses}

The database and statistical analysis was performed using SPSS v.17 software. Descriptive statistics computation techniques were applied to the discrete and continuous data. Measures such as mean, standard deviation, minimum and maximum range were developed from the continuous data. Relative frequency was calculated for discrete data. Mean with standard deviation was used to summarize the age of patients. A p-value $<0.05$ was considered as statistical significant. Bivariate analysis was performed to assess the predictors of QOL. Based on the survey, Pearson Correlation coefficient denoted by $\mathrm{r}$ was calculated to determine the type of correlation, i.e., either positive or negative correlation among variables. Paired t-test was used to compare difference between score means of different domains.

\section{Socio-demographic characteristics of the patients}

Table 1. Socio-demographic characteristics in the form of Frequency and percentage of variables of the patients and correlation in the two groups, i.e., Chemotherapy and Radiotherapy

\begin{tabular}{|c|c|c|c|c|c|c|}
\hline \multirow[t]{2}{*}{ S.No. } & \multirow[t]{2}{*}{ Variables } & \multirow[t]{2}{*}{ Parameters } & \multicolumn{2}{|c|}{ Chemotherapy } & \multicolumn{2}{|c|}{ Radiotherapy } \\
\hline & & & $\begin{array}{l}\text { Frequency } \\
\text { (n) }\end{array}$ & $\begin{array}{l}\text { Percentage } \\
\text { (\%) }\end{array}$ & $\begin{array}{l}\text { Frequency } \\
\text { (n) }\end{array}$ & $\begin{array}{l}\text { Percentage } \\
(\%)\end{array}$ \\
\hline 1. & Gender & $\begin{array}{l}\text { a. Male } \\
\text { b. Female }\end{array}$ & $\begin{array}{l}6 \\
24\end{array}$ & $\begin{array}{l}20.0 \% \\
80.0 \%\end{array}$ & $\begin{array}{l}15 \\
15\end{array}$ & $\begin{array}{l}50.0 \% \\
50.0 \%\end{array}$ \\
\hline 2. & Age & $\begin{array}{l}\text { a. } 18-30 \text { years } \\
\text { b. } 30 \\
\text { c. } 46 \\
\text { d. } 60\end{array}$ & $\begin{array}{l}5 \\
17 \\
8\end{array}$ & $\begin{array}{l}16.7 \% \\
56.7 \% \\
26.7 \%\end{array}$ & $\begin{array}{l}6 \\
15 \\
9\end{array}$ & $\begin{array}{l}20.0 \% \\
50.0 \% \\
30.0 \%\end{array}$ \\
\hline 3. & $\begin{array}{l}\text { Marital } \\
\text { status }\end{array}$ & $\begin{array}{l}\text { a. Unmarried } \\
\text { b. Married } \\
\text { c. Widow } \\
\text { d. Divorced/ } \\
\quad \text { Legally } \\
\text { separated } \\
\text { e. Others }\end{array}$ & 30 & $100.0 \%$ & $\begin{array}{l}1 \\
28 \\
1\end{array}$ & $\begin{array}{l}3.3 \% \\
93.3 \% \\
3.3 \%\end{array}$ \\
\hline 4. & $\begin{array}{l}\text { Educationa } \\
\text { l status }\end{array}$ & a. Illiterate & 1 & $3.3 \%$ & 2 & $6.7 \%$ \\
\hline
\end{tabular}


Texila International Journal of Clinical Research

Volume 3, Issue 2, Dec 2016

\begin{tabular}{|c|c|c|c|c|c|c|}
\hline & & $\begin{array}{l}\text { b. Literate } \\
\text { i. Primary } \\
\text { ii. Secondary } \\
\text { c. Tertiary }\end{array}$ & $\begin{array}{l}4 \\
10 \\
15\end{array}$ & $\begin{array}{l}13.3 \% \\
33.3 \% \\
50.0 \%\end{array}$ & $\begin{array}{l}5 \\
11 \\
12\end{array}$ & $\begin{array}{l}16.7 \% \\
36.7 \% \\
40.0 \%\end{array}$ \\
\hline 5. & Occupation & $\begin{array}{l}\text { a. Service } \\
\text { b. Business } \\
\text { c. Housewife } \\
\text { d. Freelancers } \\
\text { e. Pensioners } \\
\text { f. Domestic } \\
\quad \text { duties } \\
\text { g. Cultivation }\end{array}$ & $\begin{array}{l}3 \\
3 \\
21 \\
3\end{array}$ & $\begin{array}{l}10.0 \% \\
10.0 \% \\
70.0 \% \\
10.0 \%\end{array}$ & $\begin{array}{l}10 \\
2 \\
11 \\
1 \\
4 \\
1 \\
1 \\
1\end{array}$ & $\begin{array}{l}33.3 \% \\
6.7 \% \\
36.7 \% \\
3.3 \% \\
13.3 \% \\
3.3 \% \\
\\
3.3 \% \\
\end{array}$ \\
\hline 6. & $\begin{array}{l}\text { Type of } \\
\text { family }\end{array}$ & $\begin{array}{l}\text { a. Nuclear } \\
\text { b. Joint }\end{array}$ & $\begin{array}{l}16 \\
14 \\
\end{array}$ & $\begin{array}{l}53.3 \% \\
46.7 \% \\
\end{array}$ & $\begin{array}{l}9 \\
21 \\
\end{array}$ & $\begin{array}{l}30.0 \% \\
70.0 \% \\
\end{array}$ \\
\hline 7. & $\begin{array}{l}\text { Cohabitant } \\
\text { s }\end{array}$ & $\begin{array}{l}\text { a. Living alone } \\
\text { b. Living with } \\
\text { partner } \\
\text { c. Living with } \\
\text { partner and } \\
\text { children } \\
\text { d. Living with } \\
\text { children } \\
\end{array}$ & $\begin{array}{l}15 \\
1 \\
14\end{array}$ & $\begin{array}{l}50.0 \% \\
3.3 \% \\
46.7 \%\end{array}$ & $\begin{array}{l}4 \\
5 \\
21\end{array}$ & $\begin{array}{l}13.3 \% \\
16.67 \% \\
70.0 \%\end{array}$ \\
\hline 8. & $\begin{array}{l}\text { Annual } \\
\text { income }\end{array}$ & $\begin{array}{l}\text { a. NA } \\
\text { b. } \leq 20 \\
\text { c. } 20 \\
\text { d. } 30 \\
\text { e. } 41 \\
\text { f. } \geq 84\end{array}$ & 22 & $26.7 \%$ & 19 & $63.3 \%$ \\
\hline 9. & $\begin{array}{l}\text { Place of } \\
\text { residence }\end{array}$ & $\begin{array}{l}\text { a. Small town } \\
\text { b. Big town }\end{array}$ & $\begin{array}{l}1 \\
29 \\
\end{array}$ & $\begin{array}{l}3.3 \% \\
96.7 \% \\
\end{array}$ & $\begin{array}{l}8 \\
22 \\
\end{array}$ & $\begin{array}{l}26.7 \% \\
73.3 \%\end{array}$ \\
\hline
\end{tabular}

(All tests were performed using Pearson $\chi 2$ test for association analysis)

\section{Clinical characteristics of the patients}

Table 2. Clinicalcharacteristics in the form of Frequency and percentage of variables of the patients and correlation in the two groups, i.e., Chemotherapy or Radiotherapy

\begin{tabular}{|l|l|l|l|l|l|l|}
\hline S.No. & Variables & Parameters & \multicolumn{2}{|l|}{ Chemotherapy } & \multicolumn{2}{l|}{ Radiotherapy } \\
\cline { 4 - 7 } & & & $\begin{array}{l}\text { Frequency } \\
\text { (n) }\end{array}$ & $\begin{array}{l}\text { Percentage } \\
\text { (\%) }\end{array}$ & $\begin{array}{l}\text { Frequency } \\
\text { (n) }\end{array}$ & $\begin{array}{l}\text { Percentage } \\
\text { (\%) }\end{array}$ \\
\hline 1. & Smoking habit & $\begin{array}{l}\text { a. Non-smoker } \\
\text { b. Ex-smoker }\end{array}$ & 27 & $90.0 \%$ & 27 & $90.0 \%$ \\
& & 3 & $10.0 \%$ & 4 & $10.0 \%$ \\
\hline
\end{tabular}


Texila International Journal of Clinical Research Volume 3, Issue 2, Dec 2016

\begin{tabular}{|c|c|c|c|c|c|c|}
\hline 2. & Drinking habit & $\begin{array}{l}\text { a. Non-drinker } \\
\text { b. Ex-drinker }\end{array}$ & 30 & $100.0 \%$ & $\begin{array}{l}26 \\
4\end{array}$ & $\begin{array}{l}86.7 \% \\
13.3 \%\end{array}$ \\
\hline \multirow[t]{2}{*}{3.} & Tobacco use & a. Yes & 1 & $3.3 \%$ & 7 & $23.3 \%$ \\
\hline & & b. No & 29 & $96.7 \%$ & 23 & $76.7 \%$ \\
\hline 4. & $\begin{array}{l}\text { Health } \\
\text { insurance }\end{array}$ & $\begin{array}{l}\text { a. Yes } \\
\text { b. No }\end{array}$ & $\begin{array}{l}23 \\
7\end{array}$ & $\begin{array}{l}76.7 \% \\
23.3 \%\end{array}$ & 19 & $\begin{array}{l}63.3 \% \\
36.7 \%\end{array}$ \\
\hline 5. & $\begin{array}{l}\text { Type of health } \\
\text { insurance }\end{array}$ & $\begin{array}{l}\text { a. Government } \\
\text { medically } \\
\text { insured } \\
\text { b. TPA } \\
\text { c. Cash }\end{array}$ & $\begin{array}{l}10 \\
13 \\
7\end{array}$ & $\begin{array}{l}33.3 \% \\
43.3 \% \\
23.3 \%\end{array}$ & 11 & $\begin{array}{l}40.0 \% \\
23.3 \% \\
36.7 \%\end{array}$ \\
\hline 6. & $\begin{array}{l}\text { Support by } \\
\text { charity } \\
\text { organization }\end{array}$ & $\begin{array}{l}\text { a. Yes } \\
\text { b. No }\end{array}$ & 30 & $100.0 \%$ & 30 & $100 \%$ \\
\hline 7. & $\begin{array}{l}\text { Cancer tumor } \\
\text { location }\end{array}$ & $\begin{array}{l}\text { a. Ca Breast } \\
\text { b. Ca Head } \\
\text { c. Ca Neck }\end{array}$ & $\begin{array}{l}23 \\
1 \\
6\end{array}$ & $\begin{array}{l}76.7 \% \\
3.3 \% \\
20.0 \%\end{array}$ & $\begin{array}{l}5 \\
15\end{array}$ & $\begin{array}{l}33.3 \% \\
16.7 \% \\
50.0 \%\end{array}$ \\
\hline 8. & $\begin{array}{l}\text { Disease } \\
\text { acceptance }\end{array}$ & $\begin{array}{l}\text { a. Yes } \\
\text { b. No }\end{array}$ & $\begin{array}{l}23 \\
7\end{array}$ & $\begin{array}{l}76.7 \% \\
23.3 \%\end{array}$ & $\begin{array}{l}15 \\
15\end{array}$ & $\begin{array}{l}50.0 \% \\
50.0 \%\end{array}$ \\
\hline 9. & $\begin{array}{l}\text { Reproductive } \\
\text { age of women }\end{array}$ & $\begin{array}{l}\text { a. Pre- } \\
\text { menopausal } \\
\text { b. Menopausal } \\
\end{array}$ & $\begin{array}{l}10 \\
14 \\
\end{array}$ & $\begin{array}{l}33.3 \% \\
46.7 \% \\
\end{array}$ & 9 & $\begin{array}{l}30.0 \% \\
20.0 \% \\
\end{array}$ \\
\hline 10. & Cancer type & $\begin{array}{l}\text { a. } \text { Primary } \\
\text { cancer } \\
\text { b. Recurrent } \\
\text { cancer }\end{array}$ & 30 & $100.0 \%$ & 30 & $100.0 \%$ \\
\hline \multirow[t]{2}{*}{11.} & $\begin{array}{l}\text { Co-existence } \\
\text { of metastasis }\end{array}$ & a. Yes & 8 & $26.7 \%$ & 30 & $100.0 \%$ \\
\hline & & b. No & 22 & $73.4 \%$ & & \\
\hline \multirow[t]{4}{*}{12.} & $\begin{array}{l}\text { Chemotherapy } \\
\text { 's cycle during } \\
\text { the interview } \\
\text { of QLQ }\end{array}$ & a. $1^{\text {st }}$ & & & & \\
\hline & & b. $2^{\text {nd }}$ & 2 & $6.7 \%$ & & \\
\hline & & c. $3^{\text {rd }}$ & 15 & $50.0 \%$ & & \\
\hline & & d. $4^{\text {th }}$ & 6 & $20.0 \%$ & & \\
\hline
\end{tabular}




\begin{tabular}{|l|l|l|l|l|l|l|}
\hline & & e. $5^{\text {th }}$ & 6 & $20.0 \%$ & & \\
\hline 13 & f. $6^{\text {th }}$ & 1 & $3.3 \%$ & & \\
\hline & $\begin{array}{l}\text { Radiotherapy' } \\
\text { s cycle during } \\
\text { the interview } \\
\text { of QLQ }\end{array}$ & a. $10^{\text {th }}-15^{\text {th }}$ & & & 5 & $16.7 \%$ \\
\hline & & b. $16^{\text {th }}-20^{\text {th }}$ & & & 21 & $70.0 \%$ \\
\hline & c. $21^{\text {st }}-25^{\text {th }}$ & & & 3 & $10.0 \%$ \\
\hline & d. $26^{\text {th }} 30^{\text {th }}$ & & & 1 & $3.3 \%$ \\
\hline
\end{tabular}

(All tests were performed using Pearson $\chi 2$ test for association analysis).

Paired t-test for two overall questions of WHOQOL-Bref in Chemotherapy group $(n=30)$

Table3: Paired $t$-test for two overall questions of WHOQOL-Bref in Chemotherapy group ( $\mathrm{n}=30)$

\begin{tabular}{|c|c|c|c|c|c|c|c|c|}
\hline & \multicolumn{4}{|c|}{ Paired differences } & \multirow[t]{3}{*}{$t$-test } & \multirow[t]{3}{*}{$r$-value } & \multirow[t]{3}{*}{ df } & \multirow{3}{*}{$\begin{array}{l}\text { Sig. (2- } \\
\text { tailed) }\end{array}$} \\
\hline & \multirow[t]{2}{*}{ Mean } & \multirow[t]{2}{*}{ SD } & \multicolumn{2}{|c|}{$\begin{array}{l}95 \% \text { CI of the } \\
\text { difference }\end{array}$} & & & & \\
\hline & & & Lower & Upper & & & & \\
\hline $\begin{array}{l}\text { Pair } 7 \\
\text { Q2-DOM2 }\end{array}$ & -15.66 & 2.38 & -16.55 & -14.77 & $\begin{array}{l}- \\
36.01\end{array}$ & $\begin{array}{l}-0.395 \\
p=0.031\end{array}$ & 29 & $p<0.001$ \\
\hline $\begin{array}{l}\text { Pair } 8 \\
\text { Q2-DOM3 }\end{array}$ & -5.50 & 1.52 & -6.06 & -4.93 & $\begin{array}{l}- \\
19.74\end{array}$ & $\begin{array}{l}-0.429 \\
p=0.018\end{array}$ & 29 & $p<0.001$ \\
\hline $\begin{array}{l}\text { Pair 2 } \\
\text { Q2-DOM4 } \\
\end{array}$ & -22.56 & 2.59 & -23.53 & -21.59 & $\begin{array}{l}- \\
47.62 \\
\end{array}$ & $\begin{array}{l}-0.598 \\
p<0.001 \\
\end{array}$ & 29 & p $<0.001$ \\
\hline
\end{tabular}

It can be concluded from the above table that in the chemotherapy group, overall health was significantly correlated with the psychological domain $(r=-0.395 ; \mathrm{p}=0.031)$, social domain $(\mathrm{r}=$ 0.429; $\mathrm{p}=0.018$ ), and environmental domain $(\mathrm{r}=-0.598 ; \mathrm{p}<0.001)$ of the WHOQOL-Bref questionnaire. On the other hand, the radiotherapy group showed no significant difference.

Means and standard deviations of the two global items of the WHOQOL-Bref administered to Chemotherapy $(n=30)$ and Radiotherapy $(n=30)$ cancer patients

Table 4. Overall QOL and mean QOL scores for both Chemotherapy $(\mathrm{n}=30)$ and Radiotherapy $(\mathrm{n}=30)$ groups

\begin{tabular}{|l|l|l|l|l|}
\hline \multirow{2}{*}{ Items } & \multicolumn{3}{|l|}{ Chemotherapy group } & \multicolumn{2}{l|}{$\begin{array}{l}\text { Radiotherapy } \\
\text { Group }\end{array}$} \\
\cline { 2 - 5 } & Mean & SD & Mean & SD \\
\hline Global Quality of Life & 2.80 & 0.40 & 2.80 & 0.41 \\
\hline Global Health & 2.66 & 0.53 & 2.67 & 0.54 \\
\hline
\end{tabular}

There was no such significant difference between the mean scores of Global QOL, and Global health in the chemotherapy as well as, radiotherapy group.

Overall QOL condition and frequency for both chemotherapy and radiotherapy groups 
Table 5. Overall QOL condition and frequency for both Chemotherapy $(\mathrm{n}=30)$ and Radiotherapy $(\mathrm{n}=$ 30)groups

\begin{tabular}{|l|l|l|l|l|}
\cline { 2 - 5 } \multicolumn{1}{c|}{} & \multicolumn{2}{l|}{ Chemotherapy } & \multicolumn{2}{l|}{ Radiotherapy } \\
\hline $\begin{array}{l}\text { Overall QOL answered by } \\
\text { patients }\end{array}$ & $\begin{array}{l}\text { Cases } \\
(\mathbf{n})\end{array}$ & $\begin{array}{l}\text { Frequency } \\
(\%)\end{array}$ & $\begin{array}{l}\text { Cases } \\
(\mathbf{n})\end{array}$ & $\begin{array}{l}\text { Frequency } \\
(\%)\end{array}$ \\
\hline Very poor & 5 & $16.7 \%$ & 0 & 0 \\
\hline Poor & 17 & $56.7 \%$ & 6 & $20.0 \%$ \\
\hline Neither poor nor good & 8 & $26.7 \%$ & 24 & $80.0 \%$ \\
\hline Good & 0 & 0 & 0 & 0 \\
\hline Very good & 0 & 0 & 0 & 0 \\
\hline
\end{tabular}

It could thus be depicted from the table that 5(16.7\%), and $17(56.7 \%)$ of the patients in the chemotherapy group experienced very poor and poor QOL respectively as compared to $6(20.0 \%)$ patients' poor QOL in the radiotherapy group.

\section{Health condition and frequency for both chemotherapy and radiotherapy groups}

Table 6: Health condition and frequency for both Chemotherapy $(n=30)$ and Radiotherapy $(n=30)$ groups

\begin{tabular}{|l|l|l|l|l|}
\cline { 2 - 5 } \multicolumn{2}{c|}{} & \multicolumn{2}{l|}{ Chemotherapy } & \multicolumn{2}{l|}{} \\
\hline $\begin{array}{l}\text { Health condition answered } \\
\text { by patients }\end{array}$ & $\begin{array}{l}\text { Cases } \\
(\mathbf{n})\end{array}$ & $\begin{array}{l}\text { Frequency } \\
(\%)\end{array}$ & $\begin{array}{l}\text { Cases } \\
(\mathbf{n})\end{array}$ & $\begin{array}{l}\text { Frequency } \\
(\%)\end{array}$ \\
\hline Very poor & 7 & $23.3 \%$ & 1 & $3.3 \%$ \\
\hline Poor & 10 & $33.3 \%$ & 8 & $26.7 \%$ \\
\hline Neither poor nor good & 11 & $36.7 \%$ & 21 & $70.0 \%$ \\
\hline Good & 2 & $6.7 \%$ & 0 & 0 \\
\hline Very good & 0 & 0 & 0 & 0 \\
\hline
\end{tabular}

It was observed that patients on chemotherapy [10(33.3\%)] had more poor QOL as compared to the patients on radiotherapy treatment $[8(26.7 \%)]$.

Co-relation between inpatient and outpatient medical services and co-operation for patientreported outcomes during chemotherapy or radiotherapy

Table 7. Patient-reported outcomes of subjective QOL during inpatient chemotherapy or outpatient radiotherapy sessions.

\begin{tabular}{|l|l|l|l|l|l|}
\hline S.No & \multirow{2}{*}{ Question/Facets/Item } & \multicolumn{2}{l|}{ Chemotherapy } & \multicolumn{2}{l|}{ Radiotherapy } \\
\cline { 3 - 6 } & & Yes & No & Yes & No \\
\hline $\mathbf{1 .}$ & $\begin{array}{l}\text { Hospital and primary doctor } \\
\text { co-operation }\end{array}$ & $26(86.7 \%)$ & $4(13.3 \%)$ & $23(76.7 \%)$ & $7(23.3 \%)$ \\
\hline $\mathbf{2 .}$ & $\begin{array}{l}\text { Information about future } \\
\text { problems. }\end{array}$ & $26(86.7 \%)$ & $4(13.3 \%)$ & $26(86.7 \%)$ & $4(13.3 \%)$ \\
\hline $\mathbf{3 .}$ & $\begin{array}{l}\text { Information about managing } \\
\text { potential relapse }\end{array}$ & 26(86.7\%) & $4(13.3 \%)$ & $\begin{array}{l}30 \\
(100.0 \%)\end{array}$ & 0 \\
\hline $\mathbf{4 .}$ & $\begin{array}{l}\text { Overall satisfaction with } \\
\text { hospital service }\end{array}$ & 28(93.3\%) & $2(6.7 \%)$ & $28(93.3 \%)$ & $2(6.7 \%)$ \\
\hline $\mathbf{5 .}$ & $\begin{array}{l}\text { Confident that the treatment } \\
\text { provided was the best possible }\end{array}$ & $29(96.7 \%)$ & $1(3.3 \%)$ & $27(90.0 \%)$ & $3(15.0 \%)$ \\
\hline $\mathbf{6 .}$ & Dietitian provided & $30(100.0 \%)$ & 0 & 0 & $30(100 \%)$ \\
\hline
\end{tabular}


Texila International Journal of Clinical Research

Volume 3, Issue 2, Dec 2016

\begin{tabular}{|c|c|c|c|c|c|}
\hline 7. & Counselor provided & $30(100.0 \%)$ & 0 & 0 & $30(100 \%)$ \\
\hline 8. & $\begin{array}{l}\text { your treatment is started as } \\
\text { soon after the diagnosis as you } \\
\text { would like }\end{array}$ & $15(50.0 \%)$ & $15(50.0 \%)$ & $24(80.0 \%)$ & $6(20.0 \%)$ \\
\hline 9. & $\begin{array}{l}\text { there are regular checks to find } \\
\text { new tumors, if your type of } \\
\text { cancer is heritable }\end{array}$ & $30(100 \%)$ & 0 & $30(100 \%)$ & 0 \\
\hline 10. & $\begin{array}{l}\text { your doctor consults other } \\
\text { doctors or refers you if } \\
\text { additional expertise is required }\end{array}$ & $30(100 \%)$ & 0 & $25(83.5 \%)$ & $5(16.7 \%)$ \\
\hline 11. & $\begin{array}{l}\text { doctors and nurses in the } \\
\text { hospital give you the best } \\
\text { possible care }\end{array}$ & $30(100 \%)$ & 0 & $30(100 \%)$ & 0 \\
\hline 12. & $\begin{array}{l}\text { you regularly receive } \\
\text { information about the effect } \\
\text { (advantages and } \\
\text { disadvantages) of the } \\
\text { treatment, during the treatment } \\
\text { period }\end{array}$ & $28(93.3 \%)$ & $2(6.7 \%)$ & $23(76.7 \%)$ & $7(23.3 \%)$ \\
\hline 13. & $\begin{array}{l}\text { Care-providers inform you } \\
\text { about patient organizations }\end{array}$ & 0 & $30(100 \%)$ & 0 & $30(100 \%)$ \\
\hline 14. & $\begin{array}{l}\text { you are informed if the waiting } \\
\text { time is longer than expected }\end{array}$ & $25(83.5 \%)$ & $5(16.7 \%)$ & $25(83.5 \%)$ & $5(16.7 \%)$ \\
\hline 15. & $\begin{array}{l}\text { you receive information from } \\
\text { the hospital about possibilities } \\
\text { for psychosocial guidance, } \\
\text { during treatment sessions }\end{array}$ & $10(33.3 \%)$ & $20(66.7 \%)$ & 0 & $30(100 \%)$ \\
\hline 16. & $\begin{array}{l}\text { the waiting time for inpatient } \\
\text { and outpatient sessions in the } \\
\text { hospital is less than } 15 \text { minutes }\end{array}$ & $30(100 \%)$ & 0 & 0 & $30(100 \%)$ \\
\hline 17. & $\begin{array}{l}\text { Was it possible to discuss a } \\
\text { second opinion with your } \\
\text { doctor? }\end{array}$ & $29(96.7 \%)$ & $1(3.3 \%)$ & $24(80.0 \%)$ & $6(20.0 \%)$ \\
\hline 18. & $\begin{array}{l}\text { Did the doctors listen carefully } \\
\text { to you? }\end{array}$ & $30(100 \%)$ & 0 & $30(100 \%)$ & 0 \\
\hline 19. & $\begin{array}{l}\text { If your cancer is heritable, was } \\
\text { examination of your relatives } \\
\text { discussed? }\end{array}$ & $15(50.0 \%)$ & $15(50.0 \%)$ & $5(16.7 \%)$ & $25(83.5 \%)$ \\
\hline 20. & $\begin{array}{l}\text { Do you have to wait too long } \\
\text { to get the first available } \\
\text { appointment for a test or } \\
\text { treatment? }\end{array}$ & $25(83.5 \%)$ & $5(16.7 \%)$ & $25(83.5 \%)$ & $5(16.7 \%)$ \\
\hline
\end{tabular}

The above table depicted some of the outcomes and necessities during the chemotherapy and radiotherapy sessions that was recorded while counseling and interviewing the cancer patients.

\section{Discussion}

The data was collected after each interview from the respondent to determine if new insights were being produced from each interview. Rich data with thick description consistent with data saturation was achieved after interviews with sixty participants. Patients had limited knowledge about the side effects of chemotherapy and radiotherapy treatment and their management. Therefore, different 
aspects of QOL were differentially important to individuals. Following were some of the open ended questions discussed with the patients.

1. What things in your life help to make your life meaningful?

2. Your description of quality of life?

3. What physical things (self and environment) help to make your life meaningful?

4. What physical things (self and environment) need to be changed to make your life worth living?

5. What psychological factors help to make your life meaningful?

6. What psychological things need to be changed to make your life worth living?

7. What social things help to make your life meaningful?

8. What social things need to be changed to make your life worth living?

9. How do you spend your time each day?

10. What things you would like to change in your day to help make your life worth living?

Some of the comments included for the above series of questions included:

1. "It's hard to evaluate yourself,"

2. "My biggest complaint to doctors is that warmth is needed for all of this to register,"

3. "This journey has brought me so much closer to the Lord,"

4. "The doctor can recite the most amazing facts, but it makes me feel alone and gives me no hope,"

5. "Most of the patients included in the study were home-makers and retired. So, they like to spend their each day with daily household chores",

6. "Mindfullness therapy in the form of meditation, yoga, walk, exercise, gardening, spiritual, watching television, spending time with the family were observed to be helpful in keeping the cancer patient either undergoing chemotherapy or radiotherapy psychologically occupied",

7. "Most of the patients needed counseling during the chemotherapy or radiotherapy sessions as they were found to be severely affected by anxiety and depression".

Furthermore, the Biblical view of illness and human suffering was found to be closely related to the origin of sin and was a natural component of finite embodied human beings ${ }^{[15]}$. Enduring adversity could be used to display the work of God in a person's life and to facilitate the development of Christian character and spiritual growth ${ }^{[15]}$. The eventual realization for most of the patients was that God is all-powerful and all-knowing, and he will reward those who do good unto Him ${ }^{[15]}$. Schub and Richards (2014), stated that spirituality was the vehicle needed to allow healthcare providers to identify interventions for improving patient physical and mental health leading to overall well-being [15]. According to the Ramanakumar study, a variety of practices related to religiosity like belief in god, belief in karma, increased temple visits, increased temple activities, visiting religious place, pilgrimage, Yoga, and the belief that 'god will save' were followed in India to overcome coping, improving mood, adjustment, and decrease in distressful symptoms such as loss of appetite and fatigue in cancer patients during the treatment regimen ${ }^{[16]}$. Studies of a Patanjali-based integrated Yoga program for patients with breast cancer developed by the Vivekananda Yoga Anusandhana Samsthana (VYASA) had consistently reported improvement in anxiety, symptom severity, and distress, nausea and vomiting, and effecton global QOL as well as beneficial effects on natural-killer cell counts and radiation-induced DNA damage ${ }^{[10]}$.According to a study conducted by Thrane in 2013, showed that Mindfulness-Based Stress Reduction (MBSR) which was a group program that included mindfulness practice in the form of Mindfulness meditation and listening to meditation CDs, hypnosis, mind-body techniques (breathing exercises, distraction, positive coping behaviors, and relaxation techniques), virtual reality, creative arts therapy (dance and movement, music, and art therapy), and massage were found to be effective and significant in improving QOL of cancer patients by preventing social decline, and reduced societal costs of persons living with cancer with an object oriented aim for experiencing life fully and being in touch with the full range of internal locus of human emotions and sensory experiences and paying attention to present-moment experience nonjudgmentally ${ }^{[17,18,19]}$. According to a study conducted by Neikrug, A. Bet al. in 2012 showed that 
Texila International Journal of Clinical Research

Volume 3, Issue 2, Dec 2016

morning administration of bright light improved and strengthens Circadian rhythms (CRs) which might protect women from experiencing CR deterioration during chemotherapy ${ }^{\text {[20] }}$.

\section{Conclusion}

Treating the patient holistically, both physically and psychologically, would lead to the best patient outcomes. During the Chemotherapy sessions, it was observed that 26(86.7\%) patients found the hospital and the primary doctor was cooperative, 26(86.7\%) patients were informed about the future problems, 26(86.7\%) patients were informed about managing potential relapse, 28(93.3\%) were overall satisfied, 29(96.7\%) were confident that the treatment provided was the best possible, $30(100.0 \%)$ were provided the counselor and dietitian, 15 (50.0\%) treatment was started as soon after the diagnosis, $30(100.0 \%)$ regular check ups to find new tumors, if the type of cancer was heritable, $30(100.0 \%)$ were satisfied from the doctor's consultation and nurses care, 28 (93.3\%) regularly received information about the effect (advantages and disadvantages) of the treatment, during the sessions,25 (83.5\%) were informed about the waiting time, 10(33.3\%) patients received for psychosocial guidance during treatment sessions, 30 (100.0\%) the waiting time for inpatient sessions in the hospital was less than 15 minutes, 15 (50.0\%) were interrogated for heritable cancer, 25 (83.5\%) waited long for the first appointment.

On the other hand, during the Radiotherapy sessions, it was observed that 23 (76.7\%) patients found the hospital and the primary doctor was cooperative, 26(86.7\%) patients were informed about the future problems, 30(100.0\%) patients were informed about managing potential relapse, 28(93.3\%) were overall satisfied, 27(90.0\%) were confident that the treatment provided was the best possible, 24 $(80.0 \%)$ treatment was started as soon after the diagnosis, 30 (100.0\%) regular check ups to find new tumors, if the type of cancer was heritable, 25 (83.5\%) were satisfied from the doctor's consultation and $30(100.0 \%)$ from nurses care, 23(76.7\%) regularly received information about the effect (advantages and disadvantages) of the treatment, during the sessions,25(83.5\%) were informed about the waiting time, 5 (16.7\%) were interrogated for heritable cancer, 25 (83.5\%) waited long for the first appointment.

However, it was observed in both the groups of patients that the care-providers did not provide any information regarding patient organization. Moreover, there was a scarcity of a dietitian and a psychosocial counselor for guidance in the radiotherapy group. Also, the waiting time for the radiotherapy sessions was more than 15 minutes.

In a nutshell, it could be concluded from the above observations that cancer patients on chemotherapy had more affected QOL rather than on radiotherapy treatment. Every individual patient had different aspects and definitions of QOL.

\section{Future directions}

The subjective questionnaires could be converted into likert scale type and then further pre-testing of the same is recommended with large number of sample size.

\section{Limitations of the study}

The only limitation of the present study was small number of sample size with single-centered study.

\section{Footnotes}

Author's Contribution: 1- acquisition of data; 2- analysis and interpretation of data; 3- drafting of the manuscript; 4- critical revision of the manuscript for important intellectual content; 5- statistical analysis; 6- administrative, technical and material supports.

Funding/Support: Self-funded. 


\section{Acknowledgement}

The present study is a part of the research programme, "Assessment of Quality of Life of Adult Cancer Patients during inpatient Chemotherapy Treatment (CT), or outpatient Radiotherapy Treatment (RT) in a tertiary care hospital of New Delhi, India”.This research was supportedand assisted by at:

Department of Medical Oncology and Radiation Oncology, DR. B.L. Kapur Memorial Hospital, New Delhi, India.

Under the Supervision of:

Dr. S. Hukku (H.O.D. of Radiation Oncology Department),

DR. B.L. Kapur Memorial Hospital,

New Delhi, India.

Dr. Amit Agarwal (H.O.D. of Medical Oncology Department),

DR. B.L. Kapur Memorial Hospital,

New Delhi, India.

Under the Guidance of:

Dr. Renita Bhamrah (Texila American University),

E-mail:darpreetrenita@gmail.com

Dr. Nilesh J. Patel (Texila American University)

E-mail: nileshcology127@yahoo.co.in

\section{References}

[1]. Ali, I., Wani, Waseem, A., Saleem, K. (2011). Cancer Scenario in India with Future Perspectives. Cancer Therapy, 8,56-70.

[2]. Bushan, D. K. (2014, November 2). Cancer scenario in India. Retrieved October 18, 2016, from Daily Excelsior: http://www.dailyexcelsior.com/cancer-scenario-india/

[3]. Bronson, T. (1999). "Quality of Life of the Hemodialysis Patient". Masters Theses. Paper 531. Retrieved from: http://scholarworks.gvsu.edu/theses/531

[4]. Booij, J. C., Zegers, M., Evers, P. M., Hendriks, M., Delnoij, D. M., Rademakers, J. J.(2013). Improving cancer patient care: development of a generic cancer consumer quality index questionnaire for cancer patients. BMC Cancer, 13, 203.

[5]. Coelho, K. R. (2012). Challenges of the Oral Cancer Burden in India. Journal of Cancer Epidemiology, vol. 2012, 17 pages. doi:10.1155/2012/701932

[6]. Deshpande, P. R., Sheriff, M. K., Nazir, A., Bommareddy, S., Tumkur, A., Naik, A. N. (2013). Patientreported quality of life outcomes in Indian breast cancer patients: Importance, review of the researches, determinants and future directions. J Can Res Ther, 9, 11-6. Doi: 10.4103/0973-1482.110341

[7]. Fjorback, L. O. (2012). Mindfulness and bodily distress. Dan Med J.59 (11):B4547.

[8]. Khandelwal, S., Kurady,B. L.,M. S. V., Asha, K.,James, G.,Bharti, C. (2015). Quality of life in cancer patients on chemotherapy.Journal of Applied Pharmaceutical Science, 4(5). 918-928.

[9]. Leyendecker, Mary, R. (2015). "Spiritual Quality of Life Among Geriatric Cancer Patients: A Descriptive Correlational Study". Master of Science in Nursing Theses. Paper 17.

http://digitalcommons.cedarville.edu/nursing_theses/17

[10]. Mansano-Schlosser, Cristina, T. \& Ceolim, Maria Filomena. (2012). Quality of life of cancer patients during the chemotherapy period. Texto \& Contexto - Enfermagem, 21(3), 600- 607. https://dx.doi.org/10.1590/S0104-07072012000300015

[11]. Manoharan,N., Tyagi, B.B., Raina, V. (2009). Cancer Incidences in Urban Delhi- 2001-05. Asian Pacific Journal of Cancer Prevention, 10, 799-806.

[12]. Neikrug, A. B., Rissling, M., Trofimenko, V., Liu, L., Natarajan, L., Lawton, S., Parker, B. A., AncoliIsrael, S. (2012). Bright light therapy protects women from circadian rhythm desynchronization during chemotherapy for breast cancer. Behav Sleep Med, 10(3):202-16. Doi: 10.1080/15402002.2011.634940. 
Texila International Journal of Clinical Research

Volume 3, Issue 2, Dec 2016

[13]. Ott, M. J., Norris, R. L., Bauer-Wu, S. M. (2006). Mindfulness meditation for oncology patients: a discussion and critical review. Integr Cancer Ther, 5(2), 98-108.

[14]. Ryan, M. (2015). "Quality of Life in Adolescents with Cancer". Honors Theses.Paper 2639. http://scholarworks.wmich.edu/honors_theses/2639

[15]. Singh, H., Kaur, K., Singh, Banipal, R. P., Singh, S., Bala, R. (2014). Quality of life in cancer patients undergoing chemotherapy in a tertiary care center in Malwa region of Punjab. Indian J Palliat Care, 20, 116-22. Doi: 10.4103/0973-1075.132627

[16]. Saha, D. (2016, June 1). Delhi has the highest cancer incidence in India. Retrieved October 13, 2016, from newslaundry.com: http://www.newslaundry.com/2016/06/01/delhi-has-the-highest-cancer-incidence-in-india/\#

[17]. WHOQOL Group. (1998). Development of the World Health Organization WHOQOLBREF quality of life assessment. Psychol Med, 28:551-8.

[18]. Yeole, B.B. (2007). Trends in incidence of head and neck cancers in India. Asian Pac JCancer Prev,8(4):607-12.

[19]. Zung, W. W. K. (1971). A rating instrument for anxiety disorders. Psychosomatics, 12(6), 371-379. Available at: https://psychology-tools.com/zung-anxiety-scale/

[20].Zung, W. W. K. (1965). A Self-Rating Depression Scale. (1965). Arch Gen Psychiatry, 12: 63-70. Available at: https://psychology-tools.com/zung-depression-scale/ 